\title{
The Correlations Among Anxiety, Self-Efficacy, and Performance of Speaking at State Junior High Schools of Talang Ubi Sub-District
}

\author{
Novi Amelia ${ }^{1 *}$, Indawan Syahri ${ }^{2}$ \\ ${ }^{I}$ SMAN 6 Talang Ubi PALI \\ ${ }^{2}$ Muhammadiyah University of Palembang \\ *Corresponding author. Email: noviamelia566@gmail.com
}

\begin{abstract}
The study's objectives were to evaluate whether or not there was a significant relationship between anxiety, selfefficacy, and speaking performance. This study's population consisted of all 3089 students from state Junior High Schools in the Talang Ubi sub-district. This study's sample size was 90 students chosen using a stratified random sampling technique. Data was gathered by circulating questionnaires for anxiety and self-effectiveness, as well as checking for speaking results. Correlation Product Moment and Multiple Regression analysis were used to analyze the data. The results revealed: (1) a negative and significant correlation between anxiety and speaking performance; (2) no significant correlation between self-efficacy and speaking performance; (3) no significant correlation between anxiety and self-efficacy; and (4) positive and significant associations between anxiety, self-efficacy, and speaking performance.
\end{abstract}

Keywords: Anxiety, Self-Efficacy, Performance of Speaking

\section{INTRODUCTION}

Language is characterized from one generation to another as a means of thinking and transmitting culture as well as from one nation to another. Communication between people is often inferred. For some reasons, individuals learn more than one language. For schooling, business, social or other purposes, it may be. English is taught as a foreign language in Indonesia. The Indonesian government identified English as one of the subject curricula of the Indonesian School. It becomes a local subject in primary school, as well as subjects in junior high, senior high, and higher education institutions.

There are four skills that students need to master when learning English. Listening, listening, reading and writing are what they are. One is speaking, speaking as a productive capacity. Speaking is a message delivery activity; it is a two-way oral process between speaker and listener. In other words, the main point of speaking activity is that speakers deliver their massages to the listeners.

Speaking ability is an ability that is considered first by others than other abilities. It makes sense because testing our speaking skill takes just a few minutes for others. When someone speaks in English, we will determine how well he or she speaks directly, but we will need more time to learn other abilities. Almost all individuals only spend their time concentrating on studying grammar and memorizing words. We understand that learning written English is very important, but speaking or face-to-face practice is the most effective teaching.

In learning English language courses, the greatest hope and inspiration of students is to achieve fluency in speaking. However, learners of the English language experience a frustrated feeling of not being able to engage in speaking activities. Most students also exhibit elevated levels of anxiety when it comes to using the target language for oral communication purposes. Therefore, it is important for the teacher to find out the factors that influence their speaking ability in order to help the students resolve their speaking problems.

Several variables influence English speaking production. One of the factors affecting speaking success is anxiety. Anxiety is a feeling of tension, anxiety, and worry that can impair students' ability to perform effectively in a foreign language classroom. This means that when people are targeted, they are automatically nervous. 
Student anxiety occurs when something that is not yet happening has a sense of being challenged. The discrepancy between what students expect and the fact that happens to students related to their speaking performance is triggered by students who experience anxiety. For example, when the teacher asks students to practice in front of the class. Some of them assumed that if they made a mistake, their peers would ridicule them. As a result, they desired to be beautiful. Students experience nervousness in the classroom as a result of the disorder, which can impair their ability to communicate. Students who are nervous will have trouble following lessons and conversing. They will learn less and will be unable to apply what they have already learned. Worse, they will suffer further losses, exacerbating their anguish.

In relation to this, a preliminary study was conducted through observation and interview by the researcher at State Junior High School 11 of Talang Ubi. Based on preliminary interview to one of the English teachers at State Junior High School 11 of Talang Ubi. The researcher found that the English ability of some students were not good enough. Some students were afraid that they would make mistakes, be silent, and sound foolish when the students spoke in the classroom. They were shy when they earned the attention of the whole class. Some other students complained that they had no idea what to say about their nervousness. When they were in a group, a few students who could talk well could dominate the entire group, while others either spoke little or not at all. In class, some students used their mother-tongue if they spoke about a certain topic, they were not completely capable of. They would say words in the language of their mother tongue that they did not know. It was also the natural thing to do. They use their first languages to make the interpretation clearer.

Moreover, speaking performance results of the students at State Junior High School 11 of Talang Ubi were not as good as the other English language skills results where their average score of speaking was 55 below the minimum criteria of mastery learning (KKM). In other words, the students had difficulties in speaking. Some students thought English was a challenging subject as well. They used less acceptable vocabulary, incorrect grammar, and mispronounced some words, resulting in misunderstandings during the speech. The researcher also found that some students who had good ability in speaking were nervous, did some strange actions, and did not have any idea to say. Although they knew that they could do that and had enough ability, they were still lack of confidence while performing the topic.

The problems faced by the above students were also linked to the assumption that something is achieved or recognized as self-efficacy. Self-efficacy as one's conviction of one's ability to succeed or perform a task in specific situations [1]. Self-efficacy may also be linked to motivation. Self-efficacy is actually about someone's confidence in the ability to do the assignment that is given. Their experiences also impact their opinions on the specific task of how well they themselves are. Such personal decisions can affect the motivation of one to perform the task. Motivation meanwhile is intrinsic to the accomplishment of the objectives of each individual. Motivation can influence someone to carry out the mission.

In foreign language education, anxiety has been a subject of study. Foreign language experts believe that "anxiety is to blame for students' low performance during language learning practices" [2]. As students talk, they appear to feel nervous because they are afraid of making mistakes. In his research, [3] students with lower levels of anxiety outperformed those with higher levels of anxiety in public speaking. The data showed that speaking anxiety could contribute negatively to the performance of the overall speaking performance of the students.

Several studies have also found that self-efficacy has an effect on speaking performance. Such findings seem to emphasize the importance of focusing on the factors that influence public speaking performance. Speaking of self-efficacy values was found to be a stronger predictor of Iranian EFL learners' achievement of speaking skills in a study conducted by Speaking. Furthermore, the degree of effort, persistence, and flexibility is structured on the basis of self-efficacy beliefs.

Based on the explanations above, the researcher was motivated to conduct a research entitled "Correlations among anxiety, self-efficacy, and performance of speaking at State Junior High Schools of Talang Ubi Sub-District."

\section{METHODS}

The data obtained in this study was analyzed using a quantitative approach and a descriptive tool. This study used a quantitative approach and a descriptive method to determine whether or not there is a relationship between students' speaking anxiety and self-efficacy levels and their English-speaking results. A correlation analysis design was used in this study to determine the correlation.

A correlation study design is a quantitative research method in which the researcher measures the degree of association (or relationship) between two or more variables using the statistical technique of correlation analysis [4]. A correlation study design allows the researcher to link two or more variables (student anxiety, self-efficacy, and students' English-speaking ability).

This study's population consisted of all students from state Junior High Schools in the Talang Ubi subdistrict in the academic year 2020/2021, a total of 3089 students. 
In this analysis, a purposeful method of sampling was used, using the basic purpose of the research and personal judgement to select the sample. The sample selection was based on easily accessible to the researcher so that the expense and efforts are kept within reasonable limits. Furthermore, the school was not being closed during this pandemic Covid 19. Based on the criteria mentioned, four state junior high schools were stated as the sample of the study. They wereState Junior High School 4, State Junior High School 6, State Junior High School 9, and State Junior High School 11 of Talang Ubi in the academic year of 2020/2021 totaling 884 students.

In measuring the number of sample in this study, the researcher used Slovin formula. This formula used in determining the number of sample from this Total number of the students. Total number of the students was 884 . Technique for collecting data were conducted through speaking test and questionnaire.

\section{RESULTS AND DISCUSSIONS}

1) Correlations between anxiety and speaking performance of the eighth grade-students' at state Junior High Schools of Talang Ubi SubDistrict

In order to answer the first research questions, the result of anxiety questionnaire and speaking performance through Pearson Product Moment correlation can be seen in Table 1 .

Table 1. Correlations between Speaking Performance and Anxiety

\begin{tabular}{ccc}
\hline Correlation & $\begin{array}{c}\text { Pearson } \\
\text { Correlation }\end{array}$ & Sig. (2-tailed) \\
\hline $\begin{array}{c}\text { Speaking } \\
\text { performance }- \\
\text { Anxiety }\end{array}$ & $-.899^{* *}$ & .000 \\
\hline
\end{tabular}

For the contribution anxiety on speaking performance can be seen in Table 2 .

Table 2. Model Summary

\begin{tabular}{crrr}
\hline $\mathrm{R}$ & $\mathrm{R}$ Square & $\begin{array}{c}\text { Adjusted R } \\
\text { Square }\end{array}$ & $\begin{array}{c}\text { Std. Error of the } \\
\text { Estimate }\end{array}$ \\
\hline $.899^{\mathrm{a}}$ & .809 & .807 & 4.34964 \\
\hline
\end{tabular}

Coefficient correlation of (r) product moment of the students' anxiety and their speaking performance was 0.899 . The likelihood value indicated by the column Sig.(2-tailed) was 0.000 less than 0.05. As a result, the data verified that the coefficient correlation is greater than the $\mathrm{r}$ table. As a result, it can be deduced that $\mathrm{Ha}$ is accepted and Ho is refused. It means that there is a negative and important association between eighthgrade students' anxiety and speaking performance at Talang Ubi Sub-District state Junior High Schools.

If we interpret it based on the table of the Strength of Correlation Coefficient, it can be inferred that there is very strong correlation $(80.9 \%)$ between anxiety and speaking performance of the eighth grade-students' at state Junior High Schools of Talang Ubi Sub-District.

According to the study's results, there was a negative and substantial link between eighth-grade students' anxiety and speaking performance at state Junior High Schools in the Talang Ubi Sub-District. Based on the table of the Strength of Correlation Coefficient, we can conclude that there is a clear correlation between anxiety and speaking performance of eighth grade students at Talang Ubi Sub-District state Junior High Schools. In summary, an increase in students' anxiety is accompanied by a decline in their speaking ability. When students experience high levels of anxiety, it is possible that they may disregard their commitment to learning English. It also implies that they are being pressured to learn. [5] Formal paraphrase an anxious student tends to be less focused, forgetful, beating, and sweating, which may lead to negative behaviors such as ignoring or procrastinating their classroom assignments. These patterns can have an effect on their cognitive ability because students with high anxiety perform and achieve less progress in class than students with low anxiety.

Speaking anxiety has been shown to be negatively associated with the content of the encoded message, and the effects of speaking anxiety on speaking efficiency can be observed. Speakers discuss personal topics that necessitate the disclosure of personal feelings, opinions, and habits. Speaking anxiety has been shown to affect one's ability to speak or participate in advanced speech classes. Anxiety, which is often blamed for their resistance, should not be held solely accountable. It's one of those things. It would be pleasant to believe that, contrary to common opinion, anxiety is not as bothersome as it seems. In fact, knowing your own level of anxiety can be beneficial to you. Any kind of discomfort or awkwardness will keep the students on their toes. As a result, in order for someone to act more cautiously, we might recommend that anxiety act as a radar, alerting them to something that might cause them 
anxiety. If anxiety occurs regularly around a specific topic, it is also a sign that we need to take a closer look. When it comes to speaking as an ability, students believe they lack adequate techniques such as organizing ideas, collecting knowledge, and transferring ideas. Furthermore, they believed that their English was insufficient to express themselves clearly. They become nervous as a result of this.

The findings revealed that the students' speaking abilities varied significantly between the two schools. According to the Mann-Whitney U Test report, students with lower levels of anxiety perform better in public speaking than those with higher levels of anxiety. The next study found r2 using linear regression (0.319). According to the results, speaking anxiety will have a negative effect on the students' overall success in public speaking. Nervousness was also discovered to be the primary factor, along with worry and tension.
The outcome of this research is also consistent with [6]. In the second semester, the results of this study showed the students talking about anxiety causal factors. When speaking English in class, most students feel nervous. Some ideas are finally addressed to help students alleviate anxiety and feel more positive about speaking English in oral language classrooms.

\section{2) Correlations between self-efficacy and speaking success of eighth-grade students at Talang Ubi Sub-District state Junior High Schools}

Table 3 shows the results of the self-effectiveness questionnaire and speaking efficiency by Pearson Product Moment association in order to address the first research questions.

Table 3. Correlations between Self efficacy and Speaking performance

\begin{tabular}{cll}
\hline Correlation & $\begin{array}{l}\text { Pearson } \\
\text { Correlation }\end{array}$ & Sig. (2-tailed) \\
\hline $\begin{array}{c}\text { Speaking } \\
\text { performance }- \\
\text { Anxiety }\end{array}$ & $-.047^{* *}$ & .662 \\
\hline
\end{tabular}

For the contribution self-efficacy on speaking performance can be seen in Table 4 .

Table 4. Model Summary

\begin{tabular}{cccc}
\hline $\mathrm{R}$ & $\mathrm{R}$ Square & $\begin{array}{c}\text { Adjusted R } \\
\text { Square }\end{array}$ & $\begin{array}{c}\text { Std. Error of the } \\
\text { Estimate }\end{array}$ \\
\hline $.047^{\mathrm{a}}$ & .002 & -.009 & 9.94308 \\
\hline
\end{tabular}

The coefficient correlation of (r) product moment of the students' self-efficacy and their speaking performance was 0.047 , as shown in Table 3 . The likelihood value indicated by the column Sig.(2-tailed) was 0.662 greater than 0.05 . As a result, the data verified that the coefficient correlation is greater than the $\mathrm{r}$ table. As a consequence, it can be deduced that $\mathrm{H} 0$ is accepted and $\mathrm{Ha}$ is refused. It means that there is no substantial relationship between self-efficacy and speaking performance of eighth grade students at Talang Ubi Sub-District state Junior High Schools.

Based on the table of the Strength of Correlation Coefficient, we can conclude that there is a very poor correlation (0.2 percent) between self-efficacy and speaking performance of eighth grade students at Talang Ubi Sub-District state Junior High Schools.

The study found a positive and important relationship between self-efficacy and speaking performance among eighth grade students at Talang Ubi
Sub-District state Junior High Schools. Based on the table of the Strength of Correlation Coefficient, we can conclude that there is a strong correlation between self efficacy and speaking performance of eighth grade students at Talang Ubi Sub-District state Junior High Schools.

The trust in one's own ability to do something successfully is referred to as self-efficacy. It is both a construct of social cognitive theory and a theory of its own right. Self-Efficacy tells us that people normally only want to fail at stuff [8]. According to the findings of this research, increases in student self-efficacy are followed by increases in speech performance. If students have high self-efficacy, it opens the door for them to take their English learning seriously. Based on the description given above, the investigator can conclude that there is a significant relationship between the students' self-efficacy and their ability to communicate. Students' speaking success would therefore be affected by their level of self-efficacy. Students who have a stronger sense of self-efficacy are 
more likely to be able to communicate effectively. Their success is determined by the fact that they have the ability. [7] discovered a moderately positive association between two variables. As a result, students with high self-efficacy perform well on speaking exams, and vice versa.
3) Correlations between Anxiety and Self efficacy of the eighth grade-students' at state Junior High Schools of Talang Ubi Sub-District

Table 5 shows the results of the anxety and selfefficacy questionnaires by Pearson Product Moment correlation in order to address the first research questions.

Table 5. Correlations between Anxiety and Self efficacy

\begin{tabular}{ccc}
\multicolumn{3}{c}{ efficacy } \\
\hline Correlation & $\begin{array}{c}\text { Pearson } \\
\text { Correlation }\end{array}$ & Sig. (2-tailed) \\
\hline $\begin{array}{c}\text { Speaking } \\
\text { performance - } \\
\text { self efficacy }\end{array}$ & $-.110^{* *}$ & .301 \\
\hline
\end{tabular}

For the contribution anxiety on self efficacy can be seen in Table 6.

Table 6. Model Summary

\begin{tabular}{cccc}
\hline $\mathrm{R}$ & $\mathrm{R}$ Square & $\begin{array}{c}\text { Adjusted R } \\
\text { Square }\end{array}$ & $\begin{array}{c}\text { Std. Error of the } \\
\text { Estimate }\end{array}$ \\
\hline $.110^{\mathrm{a}}$ & .012 & .001 & 17.43770 \\
\hline
\end{tabular}

Table 5 shows coefficient correlation of (r) product moment of the anxiety and self efficacy was -0.110 . Value of probability shown by the column Sig.(2-tailed) was 0,301 higher than 0.05 . As a result, the data verified that the coefficient correlation is lower than in the $r$ table. As a result, it can be deduced that Ho is accepted and $\mathrm{Ha}$ is refused. It means that there is no substantial relationship between anxiety and self-efficacy among eighth grade students at Talang Ubi Sub-District state Junior High Schools.

If we interpret it based on the table of the Strength of Correlation Coefficient, it can be inferred that there is very weak correlation $(1.2 \%)$ between anxiety and self efficacy of the eighth grade-students' at state Junior High Schools of Talang Ubi Sub-District.

The results of the study showed that there was no significant relationship between anxiety and selfefficacy among eighth grade students at Talang Ubi Sub-state District junior high schools. Based on the table of the Strength of Correlation Coefficient, we can conclude that there is a very poor correlation between

Table 7. Correlations among Anxiety, Self-efficacy and Speaking Performance

\begin{tabular}{lcl}
\hline Correlation & F & Sig. (2-tailed) \\
\hline $\begin{array}{c}\text { anxiety and self- } \\
\text { efficacy on speaking } \\
\text { performance }\end{array}$ & 187.675 & $.000^{\mathrm{b}}$ \\
\hline
\end{tabular}

anxiety and self-efficacy of eighth grade students at Talang Ubi Sub-District state Junior High Schools.

According to most research, students with low levels of self-efficacy do not believe they can achieve their goals and therefore become depressed [8]. However, the results in this study make no difference if students have high or low levels of self-efficacy. Anxiety levels and efficacy are incompatible. This may be due to their reserved disposition, inability to express themselves in public, or the rare opportunity to speak in school. Anxiety may be said to be unrelated to self-efficacy, which seems to contradict many studies, such as [9], which discovered in an Asian setting that students are more anxious in conversational classes than in reading classes.

4) Correlations among Anxiety, Self-efficacy and speaking performance of the eighth gradestudents' at state Junior High Schools of Talang Ubi Sub-District

Table 7. displays the outcomes of the anxiety and self-efficacy questionnaires and the speaking test, which 
were evaluated using the multiple linear regression technique and the F-test in order to answer the first research questions.
For the contribution anxiety and self efficacy on speaking performance can be seen in Table 2 .

Table 8. Model Summary

\begin{tabular}{crrr}
\hline $\mathrm{R}$ & R Square & $\begin{array}{c}\text { Adjusted R } \\
\text { Square }\end{array}$ & $\begin{array}{c}\text { Std. Error of the } \\
\text { Estimate }\end{array}$ \\
\hline $.901^{\mathrm{a}}$ & .812 & .808 & 4.34261 \\
\hline
\end{tabular}

According to Table 4.20, the $\mathrm{F}$ value was 187.675 and the sig. value was 0.000 . As a result, the data verified that Fcount is greater than Ftable. As a consequence, it can be deduced that $\mathrm{Ha}$ is accepted and $\mathrm{HO}$ is refused. It means that there was a positive and important link between anxiety, self-efficacy, and speaking performance of eighth grade students at Talang Ubi Sub-District state Junior High Schools.

Based on the table of the Strength of Correlation Coefficient, coefficient correlation was 0.901 and r2= 0.812 (81.2 percent); it can be concluded that there is a very strong correlation between anxiety, selfeffectiveness, and speaking performance of eighth grade students at Talang Ubi Sub-District state Junior High Schools.

The study found a positive and important relationship between anxiety, self-efficacy, and speaking performance among eighth grade students at Talang Ubi Sub-District state Junior High Schools. Based on the table of the Strength of Correlation Coefficient, we can conclude that there is a clear correlation between anxiety, self-efficacy, and speaking performance of eighth grade students at Talang Ubi Sub-District state Junior High Schools. The performance of schools in enhancing learning quality is a collaborative effort between teachers and school principals [10]

A simple type of interaction with their mates, they find it too difficult to communicate their thoughts. They do not, therefore, talk in the classroom. Therefore, if they do not handle it, anxiety can have a negative effect on their personality. In line with the researcher's preliminary study conducted through observation and interview by the researcher at State Junior High School 11 of Talang Ubi. Based on preliminary interview to one of the English teachers at State Junior High School 11 of Talang Ubi, the researcher found that the English ability of some students were not good enough. The results of the students' speaking performance were not as good as the other English language skills results where their average score of speaking was 55 below the minimum criteria of mastery learning (KKM). In other words, the students have difficulties in speaking. Some students also believed that English is a difficult subject. They used less appropriate words, wrong grammar, and mispronounced some words which made misunderstanding while performing the speech. The researcher also found that some students who had good ability in speaking were nervous, did some strange actions, and did not have any idea to say. Although they knew that they could do that and had enough ability, they were still lack of confidence while Based on the findings and discussions in the previous chapter, the following conclusions may be presented:

\section{CONCLUSION}

Based on the results and discussions in the previous chapter, some conclusions could be presented as follows: 1) there was a substantial relationship between anxiety and speaking performance among eighth-grade students at Talang Ubi Sub-District state Junior High Schools; 2) there was no substantial relationship between self-efficacy and speaking performance of eighth grade students at Talang Ubi Sub-District state Junior High Schools; 3) there was no substantial association between anxiety and self-efficacy of eighth grade students at Talang Ubi Sub-District State Junior High Schools, and 4) there were significant associations between anxiety, self-efficacy, and speaking performance of eighth grade students at Talang Ubi Sub-District State Junior High Schools.

\section{ACKNOWLEDGMENT}

Our deepest gratitude goes to Teachers in SMAN 6 Talang Ubi PALI, Chancellor of Palembang PGRI University, Director of the Postgraduate Program of PGRI Palembang University and the Education Management Study Program of PGRI Palembang University, who have supported us in doing this extraordinary thing. This project is funded independently. We also want to thank our Education Management friends who helped us a lot in a short time frame to complete this project.

\section{REFERENCES}

[1] Bandura, A. (1997). Self-efficacy and health behaviour. Cambridge handbook of psychology, health and medicine, 160-162.

[2] Ariyanti, A. (2016). Psychological factors affecting EFL students' speaking performance. ASIAN TEFL Journal of Language Teaching and Applied Linguistics, 1(1).http://asiantefl.com/index.php/asiantefl/article/view/14

[3] Sutarsyah, C. (2017). An analysis of student's speaking anxiety and its effect on speaking performance. IJELTAL (Indonesian Journal of 
English Language Teaching and Applied Linguistics), 1(2), 143152.http://ijeltal.org/index.php/ijeltal/article/vie $\mathrm{w} / 14 / 17$

[4] Creswell, J. W. (2012). Educational research: planning. Conducting, and Evaluating.

[5] Horwitz, E. K. Horwitz, M. B. and Cope, J. (1986). Foreign language classroom anxiety. The Modern Language Journal, vol. 70, pp. 125-132, 1986.

[6] Subandowo, D. (2017, November). The Analysis of Causal Factor on Student Speaking Anxiety. In 4th UAD TEFL International Conference (pp. 109114).http://seminar.uad.ac.id/index.php/utic/art $\underline{\text { icle/view/158 }}$

[7] Maulida, N. A. (2016). The Correlation Between Students'self-Efficacy and Their Speaking Performance (Doctoral dissertation, Universitas Pendidikan Indonesia).

[8] Bandura, A. (Ed.). (1992). Self-efficacy in changing societies. Cambridge university press.

[9] Liu, M. (2013). English Bar as a venue to boost students' speaking self-efficacy at the tertiary level. English Language Teaching, 6(12), 2738.

[10] Khasanah, U., Kristiawan, M., \& Tobari. (2019). The Implementation of Principals' Academic Supervision in Improving Teachers' Professionalism in the State Primary Schools. International Journal of Scientific \& Technology Research, 8(8). 